\title{
A Decade of Chais Conferences: Introduction to the IJELL Special Series of Chais Conference 2015 Best Papers
}

\author{
Nitza Geri, Ina Blau, Avner Caspi, Yoram M Kalman, \\ Vered Silber-Varod, and Yoram Eshet-Alkalai \\ The Open University of Israel, Raanana, Israel
}

nitzage@openu.ac.il; Inabl@openu.ac.il; avnerca@openu.ac.il; yoramka@openu.ac.il; vereds@openu.ac.il; yorames@openu.ac.il

\begin{abstract}
The seventh issue of the Interdisciplinary Journal of e-Skills and Lifelong Learning (IJELL- formerly Interdisciplinary Journal of E-Learning and Learning Objects - IJELLO) special series includes a selection of best papers presented at the $10^{\text {th }}$ Chais Conference for the Study of Innovation and Learning Technologies: Learning in the Technological Era. The Chais conference 2015 was held at The Open University of Israel, Raanana, Israel, on February 10-11, 2015, and was organized by its Research Center for Innovation in Learning Technologies.

This preface presents the mission and activities of the Research Center for Innovation in Learning Technologies at the Open University of Israel. It describes the objectives and themes of the Chais conference 2015, explains the special series synergies with IJELL and the Informing Science Institute, chronicles the topics that have been published in the series, and introduces the papers included in this special selection.
\end{abstract}

Keywords: learning technologies, e-learning, information and communication technology (ICT) integration in education, diffusion of innovation, human-computer interaction, digital competencies, e-skills, lifelong learning.

\section{Introduction}

Lifelong learning is becoming a global necessity due to the rapid changes of our daily environment. E-learning is a major force for lifelong learning, whether in formal academic settings or in semi-formal settings, such as Massive Open Online Courses (MOOCs), or informal searching using the vast resources available online. The Open University of Israel (OUI) is based on dis-

Material published as part of this publication, either on-line or in print, is copyrighted by the Informing Science Institute. Permission to make digital or paper copy of part or all of these works for personal or classroom use is granted without fee provided that the copies are not made or distributed for profit or commercial advantage AND that copies 1) bear this notice in full and 2) give the full citation on the first page. It is permissible to abstract these works so long as credit is given. To copy in all other cases or to republish or to post on a server or to redistribute to lists requires specific permission and payment of a fee. Contact Publisher@InformingScience.org to request redistribution permission. tance and blended learning models and is committed to continuing reflection on and improvement of its teaching quality, through the integration of innovative learning and educational technologies. The Research Center for Innovation in Learning Technologies is the dedicated research arm of the OUI for exploring emerging technologies and developing models and strategies for their integration in teaching and learning. The main 
Introduction to the IJELL Special Series of Chais Conference 2015 Best Papers

purpose of the Center is to promote research related to improvement of instruction, using innovative learning technologies. The Center consists of a consortium of about fifty faculty members from the various OUI academic departments, who together conduct a wide range of academic activities, such as symposia, workshops, conferences, and research seminars, to encourage collaboration among researchers and to enhance the discourse on innovative learning technologies among researchers and practitioners.

The following are some of the fields of research in which the Research Center for Innovation in Learning Technologies is engaged:

- The theoretical foundations of learning, educational technology and distance education;

- Integration of innovative information and communication technologies into educational systems;

- Defining and characterizing the variables necessary for developing flexible and adaptive technology-enhanced educational strategies that accommodate students' individual needs;

- Studying the pedagogical and cognitive contributions of emerging technologies to teaching and learning.

\begin{tabular}{|c|c|c|c|c|}
\hline \multicolumn{5}{|c|}{ Table 1. A Decade of Chais Conferences } \\
\hline & Milestones & \begin{tabular}{|c|} 
Chais \\
Conference \\
Papers
\end{tabular} & \begin{tabular}{|c|} 
Chais \\
Conference \\
Posters
\end{tabular} & $\begin{array}{l}\text { IJELL } \\
\text { Special } \\
\text { Series } \\
\text { Papers }\end{array}$ \\
\hline 2006 & The first Chais conference held on March 1, 2006 & 34 & & \\
\hline 2007 & Collaboration with EDEN & 40 & 8 & \\
\hline 2008 & & 47 & 17 & \\
\hline 2009 & $\begin{array}{l}\text { IJELLO (currently IJELL) special series of Chais } \\
\text { conference best papers launched }\end{array}$ & 47 & 11 & 13 \\
\hline 2010 & $\begin{array}{l}\text { The Research Center for Innovation in Learning } \\
\text { Technologies is inaugurated }\end{array}$ & 39 & 15 & 9 \\
\hline 2011 & & 42 & 9 & 9 \\
\hline 2012 & $\begin{array}{l}\text { - } \quad \text { Chais conference becomes a two-day event } \\
\text { - } \quad \text { The first Best Student Paper Award conferred }\end{array}$ & 40 & 30 & 8 \\
\hline 2013 & & 40 & 32 & 5 \\
\hline 2014 & & 36 & 41 & 5 \\
\hline 2015 & $\begin{array}{l}\text { The tenth Chais conference held on February 10- } \\
11,2015\end{array}$ & 34 & 34 & 10 \\
\hline & A Decade of Chais Conferences & 399 & 197 & 59 \\
\hline
\end{tabular}

"Learning in the Technological Era" is a series of annual national research conferences on innovation in learning technologies, initiated in 2006 by the Chais Research Center. The Research Center for Innovation in Learning Technologies is committed to continue this important research activity, under the name of the Chais conference, which commemorates the contribution of the 
late Stanley Chais, who funded the establishment of the Chais Center, later closed in 2010. The Chais conference contributes to the formation of a community of Israeli researchers in the field of learning technologies and to the positioning of the Open University of Israel as a leading organization in the study and implementation of learning technologies. During the first years, the Chais conference collaborated with EDEN, The European Distance and E-Learning Network, and abstracts of the conference papers were distributed to EDEN members, in an effort to encourage international research collaborations. This year we celebrated a decade of Chais conferences. Table 1 depicts some milestones of the Chais conference, along with quantitative data about the number of papers and the posters that were presented at the conference, as well as the papers published in the IJELL (formerly, IJELLO) special series of Chais conference best papers. The main topics of the Chais conference during this decade are elaborated below.

The 600 participants attending the two-day Chais conference 2015, represented most of Israel's universities and academic colleges, as well as organizations and corporations dealing with learning and training. The opening keynote guest lecturers were Yochai Benkler (Harvard University, USA), whose talk was entitled "Open Network Innovation and Exploration: Drivers, Benefits, and Challenges", and Sarah Guri-Rosenblit (The Open university of Israel), with a talk entitled "Distance Education in the Digital Era: an Identity Crisis?". The closing lecturers were Sarit Kraus (Bar-Ilan University, Israel), whose lecture's title was "Intelligent Computer Systems which have Human Communication Skills", and Yoav Yair (The Interdisciplinary Center Herzliya, Israel), who talked about "Sustainability, Technology and in Between". The videos of these keynotes, as well as those of all the prior Chais conferences, many of them in English, are available on the website of the Research Center for Innovation in Learning Technologies (http://www.openu.ac.il/innovation/keynotes.html).

The purpose of the special series of selected Chais conference best papers is to increase the international impact of the Chais conference by distributing high quality papers from the national conference to a worldwide audience. The Informing Science Institute (ISI) is supporting this enterprise for the seventh time. ISI is a natural partner for this mission since it draws together researchers and practitioners of information technologies, who seek effective ways to inform clients about sharing their knowledge with others (http://www.informingscience.org/). The informing science transdiscipline studies the informing process, defined as providing a specific clientele with information in a form, format, and schedule that maximizes its effectiveness (Cohen, 1999, 2009; Cohen \& Lloyd, 2014). Technologies for learning, teaching and training, are a certain type of information technologies, which aim at providing students and other learners with information and tools to enhance their learning. Within the ISI journals, the Interdisciplinary Journal of eSkills and Lifelong Learning (IJELL) publishes high quality scholarly articles on theory, practice, innovation, and research that cover all aspects of e-skills, e-learning, and lifelong learning (http://www.ijell.org). IJELL is the new name of the Interdisciplinary Journal of E-Learning and Learning Objects (IJELLO), and the journal's current focus on e-skills and lifelong learning strengthens its synergy with the scope of the Chais conferences.

The first selection in the IJELL special series of Chais conference best papers was published six years ago. Table 2 depicts the main themes of the papers that were published during the first six years of the series. The preface of each selection provides an overview of the papers that were published in that year (Eshet-Alkalai, Caspi, Eden, Geri, \& Yair, 2009, 2010; Geri, Caspi, Eden, Kalman, Yair, \& Eshet-Alkalai, 2012, 2013; Geri, Caspi, Kalman, Silber-Varod, Yair, \& EshetAlkalai, 2014; Geri, Yair, Caspi, Eden, \& Eshet-Alkalai, 2011). All the papers in the special series are listed on the website of the Research Center for Innovation in Learning Technologies (http://www.openu.ac.il/innovation/ijello.html), with links to the full versions, which are available on the IJELL website (http://www.ijell.org), as per the open access policy of the Informing Science Institute. 


\begin{tabular}{|l|l|}
\hline \multicolumn{2}{|c|}{ Table 2. Themes of former IJELL special series of Chais conference best papers } \\
\hline 2009 & $\begin{array}{l}\text { Various aspects of technology integration in teaching and learning, collaborative learning } \\
\text { environments, quality of mobile learning, motivation for technology use }\end{array}$ \\
\hline 2010 & $\begin{array}{l}\text { Integration of technology in education systems, diffusion of innovation in learning envi- } \\
\text { ronments, mobile culture, school versus home learning, collaborative learning, social as- } \\
\text { pects of learning and online communication }\end{array}$ \\
\hline 2011 & $\begin{array}{l}\text { The role of teachers in integrating innovative educational technologies, effectiveness of } \\
\text { electronic performance support systems, online video-based distance learning, Smart } \\
\text { Classrooms, teachers in a world of change, collaboration among teachers }\end{array}$ \\
\hline 2012 & $\begin{array}{l}\text { Innovative technologies for teaching and learning, instruction in technological environ- } \\
\text { ments, perceptions of online teaching and learning, cognitive aspects of learning in techno- } \\
\text { logical environments, simulations for instruction and learning }\end{array}$ \\
\hline 2013 & $\begin{array}{l}\text { Effectiveness of open educational resources, evaluation of technology-enhanced teaching } \\
\text { and learning, learning from digital content and e-books, virtual reality applications for } \\
\text { learning, technology in the service of people with special needs }\end{array}$ \\
\hline 2014 & $\begin{array}{l}\text { Effectiveness of educational gamification, increasing student interest and motivation via } \\
\text { online learning environments, teachers and teaching in a digital world, Twitter as an e- } \\
\text { mentoring mechanism, technology integration in a teacher-education program, accounta- } \\
\text { bility in educational organizations }\end{array}$ \\
\hline
\end{tabular}

The seventh selection of the Chais conference 2015 best papers comprises ten papers presented in the following Section. The Chais conference best student paper award was given for the fourth time. Sixteen of the papers that were accepted for presentation at the Chais conference 2015 were candidates for the Best Student Paper Award. This special issue includes extended versions of five of the eight finalists of the Chais conference 2015 Best Student Paper Award.

\section{Chais Conference 2015 Best Papers}

On its tenth year, 87 papers were submitted to be considered for presentation at the Chais conference 2015. After a double-blind peer-review process, 34 papers and 34 posters were accepted for presentation at the conference and were included in the conference's proceedings volume (EshetAlkalai, Blau, Caspi, Geri, Kalman, \& Silber-Varod, 2015). This seventh selection of the IJELL Special Series of the Chais Conference Best Papers contains ten of the most remarkable Chais conference 2015 papers, which have been expanded and edited for publication in IJELL and were subject to a full review process by IJELL's Editors and reviewers.

The papers in this special selection represent diverse aspects of e-skills and lifelong learning. The first paper by Dorit Geifman and Daphne R. Raban is entitled "Collective problem-solving: The role of self-efficacy, skill, and prior knowledge". Their novel research investigates the manifestation of self-efficacy in computer-mediated collaborative environments and its effect on the collective outcome. Geifman and Raban conducted a controlled experiment, which involved 632 participants in 47 prediction markets who traded a solution to a complex problem. Geifman and Raban's findings demonstrate that predictive markets are resilient to traders' self-efficacy and are an effective collective problem-solving platform. These results have important insights for collective learning, as well as crowdsourcing and reliance on the wisdom of the crowd. 
The second paper, by Yair Levy and Michelle M. Ramim, “An assessment of competency-based simulations on e-learners' management skills enhancements", considers competency-based learning (CBL). As the trend of crediting higher education students for skills and competences grows, there is an increasing need to evaluate the added value of certain tools and learning methods in helping students gain or improve their tangible skills and competences, especially in e-learning settings. Levy and Ramim developed a quasi-experiment and used surveys to collect data on a set of 12 management skills from a group of e-learners attending courses that included competencybased digital simulations, and a control group of e-learners whose courses did not include such simulations. Their findings demonstrate the added value of digital simulations and competencybased projects, beyond the mere instruction of the subject matter, in increasing management skills of e-learners.

Noa Aharony and Miri Shonfeld's paper, "ICT use: Educational technology and library and information science students' perspectives - An exploratory study", investigated the extent of influence that several factors may have on information and communication technology (ICT) use. The theoretical factors were drawn from the Diffusion of Innovation theory and the Big Five approach, as well as motivation. Their findings suggest that instructors who would like to enhance their students' ICT use should be aware of individual differences, as well as emphasize the advantages of ICT for increasing student motivation to use ICT. Furthermore, second and third year students used more ICT than first year students suggesting that, although both were technology oriented, as these programs of study progressed, students adapted their ICT use.

The following three papers are focused on instructors and concern design of teaching or training materials. The paper written by Keren Sarah Levy, Yael Kali, and Tali Tal, "Teachers as designers of technology-enhanced outdoor inquiry", was a finalist for the best student (Keren Sarah Levy) paper award of the Chais conference 2015. Their design-based research involved 24 teachers in a professional development (PD) program who were engaged in adapting a learning environment, which included mobile technologies and was intended for supporting outdoor inquiry. The in-depth study, which examined the whole PD process, included analysis of observations, questionnaires, interviews, as well as the adapted learning-environments. Levy et al.'s findings demonstrate that a "Teachers as Designers" approach may support learning, growth and professional development of teachers.

Open Educational Resources (OERs) may serve for organizational training. Although there is substantial literature on OER usage in education, there is limited research of OER usage in business settings. The paper "OER usage by instructional designers and training managers in corporations" by Eli Merkel and Anat Cohen, was also a finalist for the best student (Eli Merkel) paper award of the Chais conference 2015. The study distinguished between Little OER repositories such as YouTube, which were not necessarily designed for educational purposes, and Big OER repositories. Merkel and Cohen's main findings reveal greater use of Little OER repositories that involve revising, modifying, and combing resources by the users, and they suggest such adaptation is required due to the general nature of the materials.

The next paper concerns acquiring pedagogical e-skills. Yehuda Peled, Ina Blau, and Ronen Grinberg's paper, "Does one-to-one (1:1) computing in a junior high-school change the pedagogical perspectives of teachers and their educational discourse?", was a finalist for the best student (Ronen Grinberg) paper award of the Chais conference 2015. This longitudinal study, which lasted three years, was conducted in 1:1 classrooms, in which both teacher and students have personal digital devices, and included interviews and lesson observations. The main conclusion from this study is that transformation of a school from traditional teaching and learning to a 1:1 classroom should start with teachers' perceptions and attitudes. The mere application of personal technology is not enough for eliciting pedagogical changes. 
Introduction to the IJELL Special Series of Chais Conference 2015 Best Papers

The next two papers discuss social aspects of learning, and study social network sites (SNSs). Both investigate Facebook, while the first paper deals with general use of the SNS and the second one concerns dedicated online learning groups on Facebook. The paper "Teacher-student relationship and SNS-mediated communication: Perceptions of both role-players" by Alona ForkoshBaruch, Arnon Hershkovitz, and Rebecca Ang, examines perceptions of both teachers and students of communication via SNSs. This controversial issue is sometimes regulated, and in some countries, such as Israel, communication of teachers with elementary, junior-high, and high school students via SNSs is banned. Findings of this survey-based research, which included 160 teachers and 587 students, suggest several differences between those who are willing to connect versus those who are not willing to connect via SNSs, and may provide some interesting insights for future research, as well as for policymakers.

The mere availability of learning technologies is not enough for increasing social inclusion. As the next paper demonstrates, adopting a design-based approach, which includes carefully planned interventions, may improve social inclusion of minority groups. The paper written by Meital Amzalag, Nelly Elias, and Yael Kali, "Adoption of online network tools by minority students: The case of students of Ethiopian origin in Israel", was another finalist for the best student (Meital Amzalag) paper award of the Chais conference 2015. The findings show that before the intervention, the main pattern of college students of Ethiopian origin participation in online social learning groups was peripheral and limited to content viewing. However, after a series of two interventions, the level of their online activity increased, and indicators of their social integration were slightly improved. Furthermore, a change was observed in the usage of online learning groups by the students of Ethiopian origin, from social to academic uses.

Increasing student interest in Science, Technology, Engineering, and Mathematics (STEM) is one of the main global challenges of education systems. The paper "Will a black hole eventually swallow the earth?' Fifth graders' interest in questions from a textbook, an open educational resource and other students' questions", by Hani Swirski and Ayelet Baram-Tsabari, was also a finalist for the best student (Hani Swirski) paper award of the Chais conference 2015. The paper provides some interesting insights regarding ways to increase elementary school students' interest in science. The paper highlights the potential of Open-Educational-Resource (OER) websites, such as Ask-An-Expert, as a promising indicator of student interest in science, which could contribute to improved interest in the science curriculum.

The final paper of this special selection, written by Karen Spektor-Precel and David Mioduser, presents a pioneering study, titled: "5-7 year old children's conceptions of behaving artifacts and the influence of constructing their behavior on the development of Theory of Mind (ToM) and Theory of Artificial Mind (ToAM)". The study used quantitative and qualitative methods for investigating whether and how children develop ToAM, which is a new theoretical scheme that is distinct from their ToM. The authors used a special robot, designed for young children, "RoboGan", as a behaving artifact. Spektor-Precel and Mioduser's quantitative findings indicated that for both age groups, interaction with the robot, whether as observers or constructors, brought children's ToM into awareness, and affected their understanding of the independent behavior of robots. Their qualitative analysis revealed that the ToAM, of both constructors and observers, was influenced by their participation in the intervention.

These diverse 10 papers represent the main themes discussed at the Chais conference 2015. Additional major themes presented at the conference that were not included in this special selection are visual-based learning; mobile learning; technology in the service of people with special needs; ethics on the net. 


\section{Conclusion and Acknowledgements}

This seventh issue of IJELL's special selection of the Chais conference best papers provides discussions of some of the current research in learning technologies, which serve as a main means for supporting lifelong learning. We hope these papers will be of interest to the readers and will encourage future innovative and synergistic learning technologies research. We look forward to the IJELL next issue of the best papers of the eleventh Chais conference for the study of innovation and learning technologies. The Chais conference 2016 will be held on February 16-17, 2016, at the Open University of Israel campus in Raanana, Israel.

The publication of this special selection is enabled by the efforts and help of many people. We are grateful to Gila Kurtz, the Editor-in-Chief of IJELL for continuing this special series of Chais conference best papers and for enthusiastically supporting this editorial project.

We would like to express our heartfelt gratitude to Janice Whatley, the former Editor-in-Chief of the Interdisciplinary Journal of E-Learning and Learning Objects (IJELLO), and the Editor of this IJELL selection of Chais conference 2015 best papers, for her devoted support, and for conducting this editorial effort. On behalf of the authors, we extend our deep appreciation, and thank Janice Whatley for her helpful guidance.

We acknowledge our gratitude to Eli Cohen and Betty Boyd of the Informing Science Institute for enabling the production of this special series. We are grateful to Betty Boyd for her publishing work and for assisting the authors with the presentation of their work.

Special thanks to our colleague and friend, Yoav Yair, for many years of fruitful collaboration. Among his numerous contributions, Yoav has been an active member of the leading team of the Research Center for a decade, one of the initiators of the Chais conference, served as Organizing Committee Chair for the first two years of the conference, and participated in the first six selections of Chais conference best papers (Eshet et al., 2009, 2010; Geri et al., 2011, 2012, 2013, 2014). Furthermore, Prof. Yoav Yair served as Chair of the Inter-University Center for eLearning (IUCEL), Israel, and advanced national collaboration in improving e-learning and educational technologies dissemination and use.

We would like to praise and thank all the contributing authors and reviewers for their excellent work. Finally, many thanks to the community of Israeli researchers and practitioners of learning technologies, for their ongoing participation in Chais conferences, and for contributing to the development of this important field.

\section{References}

Cohen, E. (1999). Reconceptualizing information systems as a field of the transdiscipline informing science: From ugly duckling to swan, Journal of Computing and Information Technology, 7(3), 213-219.

Cohen, E. (2009). A philosophy of informing science. Informing Science: the International Journal of an Emerging Transdiscipline, 12, 1-15. Retrieved from http://inform.nu/Articles/Vol12/ISJv12p001015Cohen399.pdf

Cohen, E., \& Lloyd, S. (2014). Disciplinary evolution and the rise of the transdiscipline. Informing Science: the International Journal of an Emerging Transdiscipline, 17,189-215. Retrieved from http://www.inform.nu/Articles/Vol17/ISJv17p189-215Cohen0702.pdf

Eshet-Alkalai, Y., Blau, I., Caspi, A., Geri, N., Kalman, Y. M., \& Silber-Varod, V. (Eds.). (2015). Proceedings of the 10th Chais Conference for the Study of Innovation and Learning Technologies: Learning in the technological era. Raanana: The Open University of Israel. 
Eshet-Alkalai, Y., Caspi, A., Eden, S., Geri, N., \& Yair, Y. (2009). Introduction to the IJELLO special series of Chais Conference 2009 best papers. Interdisciplinary Journal of E-Learning and Learning Objects, 5, 181-186. Available at: http://ijello.org/Volume5/IJELLOv5p181-186ChaisPreface.pdf

Eshet-Alkalai, Y., Caspi, A., Eden, S., Geri, N., \& Yair, Y. (2010). Challenges of integrating technologies for learning: Introduction to the IJELLO special series of Chais Conference 2010 best papers. Interdisciplinary Journal of E-Learning and Learning Objects, 6, 239-244. Retrieved from http://www.ijello.org/Volume6/IJELLOv6p239-244Intro.pdf

Geri, N., Caspi, A., Eden, S., Kalman, Y. M., Yair, Y., \& Eshet-Alkalai, Y. (2012). Introduction to the IJELLO special series of Chais Conference 2012 best papers. Interdisciplinary Journal of E-Learning and Learning Objects, 8, 65-71. Retrieved from http://www.ijello.org/Volume8/IJELLOv8p065-071ChaisPreface.pdf

Geri, N., Caspi, A., Eden, S., Kalman, Y. M., Yair, Y., \& Eshet-Alkalai, Y. (2013). Introduction to the IJELLO Special Series of Chais Conference 2013 Best Papers. Interdisciplinary Journal of E-Learning and Learning Objects, 9, 193-199. Retrieved from http://www.ijello.org/Volume9/IJELLOv9p193199Preface.pdf

Geri, N., Caspi, A., Kalman, Y. M., Silber-Varod, V., Yair, Y., \& Eshet-Alkalai, Y., (2014). Introduction to the IJELLO special series of Chais Conference 2014 best papers. Interdisciplinary Journal of ELearning and Learning Objects, 10, 123-130. Retrieved from http://www.ijello.org/Volume10/IJELLOv10p123-130ChaisIntroduction.pdf

Geri, N., Yair, Y., Caspi, A., Eden, S., \& Eshet-Alkalai, Y. (2011). Learning and teaching in the technological era: Introduction to the IJELLO special series of Chais Conference 2011 best papers. Interdisciplinary Journal of E-Learning and Learning Objects, 7, 205-211. Retrieved from http://www.ijello.org/Volume7/IJELLOv7p205-211ChaisIntro.pdf

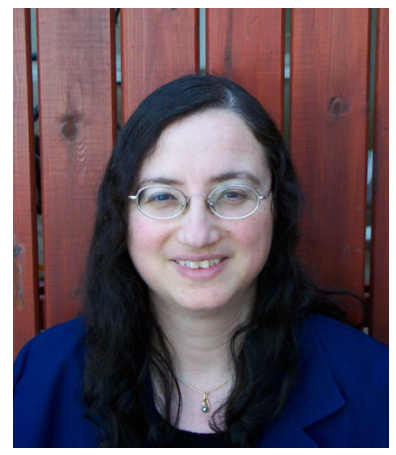

\section{Biographies}

Nitza Geri is an Associate Professor at the Open University of Israel, Department of Management and Economics, and Head of the Research Center for Innovation in Learning Technologies. She holds a B.A. in Accounting and Economics, an M.Sc. in Management Sciences, and a $\mathrm{Ph} . \mathrm{D}$. in Technology and Information Systems Management from TelAviv University. Nitza is a CPA (Israel) and prior to her academic career she had over 12 years of business experience. Her research interests and publications focus on various aspects of the value of information and knowledge, as well as adoption, implementation, and continued use of information systems, including strategic information systems, e-business, information economics, attention economy,

knowledge management, value creation and the Theory of Constraints, managerial aspects of elearning systems. Personal site: http://www.openu.ac.il/Personal_sites/nitza-geri.html

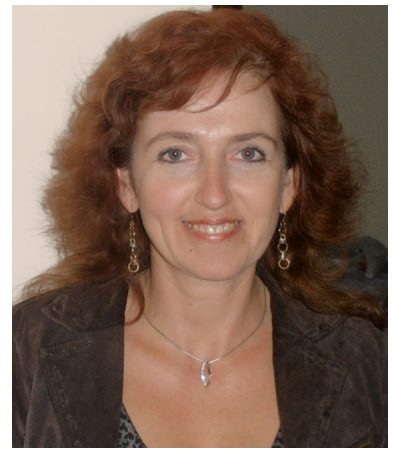

Ina Blau is a Senior Lecturer in the Department of Education and Psychology at the Open University of Israel. She holds a Ph.D. in ELearning and Cyber-Psychology from the University of Haifa, Israel. Her research interests include social aspects of e-communication and eleadership, integration of innovative technologies in K-12, academia and organizations, mobile learning and interaction, digital literacy skills, online privacy in social networking, and psychological ownership in e-collaboration. Personal site: http://www.openu.ac.il/Personal_sites/ina-blau/ 


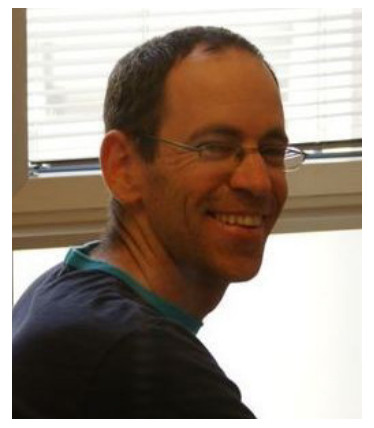

Avner Caspi is a Senior Lecturer at the Open University of Israel, Department of Education \& Psychology. He holds a B.A. in Behavioral Sciences (Tel-Aviv Yaffo Academic College), and Ph.D. in Cognitive Psychology (Tel Aviv University). His major research and publications interests focus on social aspects of communication technologies, mainly in the area of learning and instruction. Personal site: http://www.openu.ac.il/Personal_sites/avner-caspi.html

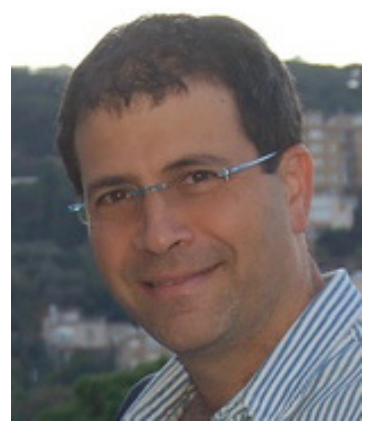

Yoram M Kalman is a Senior Lecturer at The Open University of Israel's department of Management and Economics. He studies the impact of digital technologies on people, organizations and society. His research focuses on aspects of computer-mediated communication (CMC), human-computer interaction (HCI), information systems (IS) and computer supported cooperative work (CSCW). Yoram led the Open University's massive online open courses (MOOC) initiative. Personal site: http://www.kalmans.com.

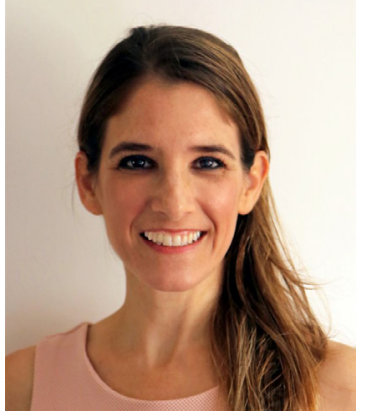

Vered Silber-Varod is a Research Fellow with The Research Center for Innovation in Learning Technologies, The Open University of Israel, Ra'anana. She received the B.A. in Political Science and French language and literature studies from the Hebrew University of Jerusalem in 1996 and M.A. degree with Magna Com Lauda in Hebrew language studies at the department of Hebrew and Semitic languages from Tel Aviv University in 2005 and the Ph.D. degree from Tel Aviv University in 2012. From 2005 to 2007, she was a Coordinator of the course Modern Hebrew phonology with the Open University of Israel. From 2009 to 2013, she was a Linguist at the ACLP - Afeka Center for Language Processing, Afeka College of Engineering. She is the author of a book, journal articles, and conference proceedings papers. Her research interests include speech prosody, acoustic phonetics, speech technologies, and quantitative analysis of written and spoken texts. Personal site: http://www.openu.ac.il/Personal_sites/vered-silber-varod/index.html

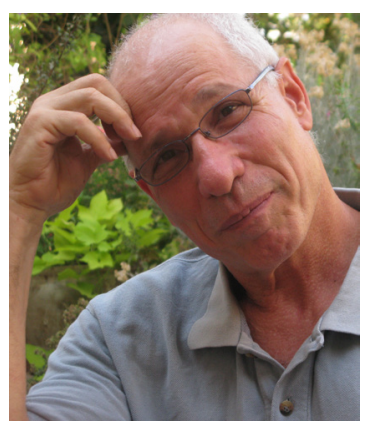

Yoram Eshet-Alkalay is a Professor at the Open University of Israel, Department of Education \& Psychology. He is Head of the M.A. program in educational technology, and the former Head of the Research Center for Innovation in Learning Technologies in the Open University. He holds a B.A. in Archeology (Hebrew University), M.Sc. in Geology (Hebrew University) and Ph.D. in Earth \& Environmental Sciences (City University of NY). For a decade, he was the Head of the Instructional Design Program in the Tel Hai Academic College, and a senior researcher in the Geological Survey of Israel. He has 15 years of experience in developing technology-based instructional solutions for educational systems in Israel and the USA. In this capacity, he was involved in the design of hundreds of simulations, data-bases, tutorials and large-scale curriculum integration projects. His major research and publications interests focus on cognitive aspects of working with digital technologies, digital games and design principles of computer-based learning environments. Personal site: http://www.openu.ac.il/Personal_sites/yoram-eshet.html 